\title{
Posisi IPS, Tantangan Masa Depan, dan Alternatif Baru
}

\author{
SARDIMAN AM \\ Fakultas Ilmu Sosial Universitas Negeri Yogyakarta \\ sardiman@uny.ac.id
}

\begin{abstract}
Abstrak
Berbicara soal pendidikan IPS di Indonesia memang menarik tetapi kadang juga melelahkan. Perdebatan panjang sejak tahun 1975 sampai sekarang belum mampu merumuskan hakikat pendidikan IPS di sekolah secara memuaskan, baik menyangkut substansi kajian maupun model pembelajarannya. Pada hal IPS di sekolah ini memiliki peran yang strategis dalam mengantarkan peserta didik untuk berlatih berpikir kritis dan kemampuan serta keterampilan untuk ikut berpartisipasi dalam memecahkan masalah sosial kebangsaan. Dengan demikian posisi pendidikan IPS di sekolah ini menjadi semakin strategis untuk masa-masa ke depan.Oleh karena itu, diperlukan pemikiran dan alternatif baru dalam pengembangan substansi kajian atau standar isi IPS di sekolah. Terutama untuk jenjang SMP dan yang sederajat.
\end{abstract}

Kata kunci: hakikat IPS, memecahkan masalah, alternatif baru

\begin{abstract}
The discussion about social sciences education issues in Indonesia is interesting but it is also tiring. A long debate from 1975 to now cannot formulate the essence of social sciences education at schools satisfactorily concerning its substance and learning model. Whereas, social sciences at schools has played a strategic role in bringing students to have critical thinking, competence, and skill to participate in solving social-nationality problems. Thus, the position of social sciences education at schools becomes more strategic for future times. Therefore, it needs new alternatives and thinkings in developing the substance or standard contents of social sciences at schools, especially for junior school level and its equal level.
\end{abstract}

Keywords: essence of social sciences, solving problems, new alternatives. 


\section{PENDAHULUAN}

Mengkaji kembali posisi IPS untuk masa depan merupakan sesuatu yang menarik dan mendesak untuk segera dilakukan. Pasalnya, di Indonesia tidak banyak para ahli apalalagi masyarakat umum yang secara khusus tertarik untuk berbicara soal IPS. IPS dipandang bukanlah sebuah instrument kemajuan dan apalagi dikaitkan dengan kemakmuran materiil. Bahkan masih ada ilmuwan kita yang memandang IPS dan atau pendidikan Ilmuilmu Sosial merupakan substansi kajian yang tidak penting dan tidak memiliki value added bagi kehidupan masyarakat.

Kalau begitu masih perlukah kita berbicara soal "Social Studies in the Era of AFTA 2015?" masih relevankah kita mengkaji IPS menghadapi tantangan tahun 2015 bahkan untuk tahun-tahun berikutnya Tentu dari yang sedikit para para pemerhati IPS, terutama yang konsen pada pendidikan kemanusiaan justru semakin tertantang untuk mengkaji IPS. Apalagi dikaitkan dengan pernyataan Albert Eistein bahwa kegalan pembelajaran IPS ( politik dan yang sejenisnya) akan dapat merusak sendi-sendi kehidupan berbangsa dan bernegara (Zamroni, 2011). Oleh karena itu, membahas IPS dan tantangan masa depan menjadi topik yang sangat penting dan mendesak.

Berbicara soal IPS dan tantangan masa depan, mengingatkan kita kepada beberapa kajian dari para futuurolog. Misalnya tentang "Future Shock" dan juga The Third Wave-nya dari Alvin Toffler (tahun 1980-an), Megatreds 2000-nya dari John Naisbitt. Intinya berbagai perubahan mendasar telah terjadi begitu cepat karena pertambahan penduduk dan kemajuan IPTEK. Manusia harus mengikuti irama perubahan tersebut. Terjadilah perubahan karakter di setiap manusia dan setiap bangsa. IPTEKS, berkembang super cepat dengan berbagai perubahan yang kadang tidak mampu dikendalikan oleh manusia pendukungnya. Itulah perkiraan-perkiraan yang diduga bakal terjadi dalam kehidupan umat manusia di dunia abad XXI.

Bagaimana manusia Indonesia merespon itu semua? Sebagai contoh ada sebuah diskusi yang disponsori Harian Kompas pada akhir tahun 1989 di Jakarta yang mempertemukan berbagai pakar dari berbagai disiplin untuk merumuskan karakter masyarakat Indonesia Baru menapaki kehidupan di abad XXI. Dalam diskusi itu disimpulkan suatu gambaran nonmatif teoritis-ideal manusia baru Indonesia yang berintikan tiga ciri utama yakni: manusia sadar IPTEKS, manusia kreatif, dan manusia beretika solidaritas (I Gde Widja, 1991:3). Mampukan pembelajaran IPS mengiringi dan memberi andil terhadap kehidupan masyarakat Indonesia dengan tiga ciri utama tersebut? Pertanyaan ini menarik untuk dicari jawabnya.

\section{Problematika Teknologis}

Memasuki abad XXI kehidupan umat manusia di dunia mulai memasuki tahapan globalisasi yang semakin kompleks. Dunia berkembang tanpa batas ruang dan waktu, penuh ketidakpastian,, IPTEK berkembang secara berlipat tiap tahunnya, terutama teknologi informasi. Format kehidupan ekonomi juga tergantung kepada perkembangan teknologi. Kebutuhan manusia tentang sesuatu akan dapat secara cepat terpenuhi. Sementara dilihat dari dimensi kebudayaan, kehidupan manusia akan ditandai dengan empat kultur: reifikasi, manipulasi, fragmentasi, dan individualisasi (Lih. (I Gde Widja, 1991.). Implikasi dari empat kultur itu akan melahirkan pola kehidupan masyarakat Indonesia yang cenderung materialistis, legalistis, dan formalistis. Semua fenomena dan realitas kehidupan harus dimanifestasikan dalam bentuk simbol-simbol fisik yang bisa diobsevasi dan diukur, diwujudkan dalam angka-angka. Yang bersifat teknis menjadi tujuan dan yang hakikat terabaikan. Teknologi yang sebenarnya menjadi fasilitas kehidupan tetapi tidak jarang telah merendahkan martabat diri dan merampas kemerdekaan manusia yang berakal dan bernuarni. Dengan demikian perkembangan IPTEK di abad XXI itu dalam konteks kehidupan sosial, di satu sisi untuk mengangkat martabat manusia karena berbagai kemudahan yang diberikan teknologi sehinagga manusia lebih banyak berkarya, tetapi di sisi lain teknologi telah melindas hakikat kemanusiaan manusia itu sendiri. 
Berbagai bentuk instrumentalia kehidupan mungkin dapat kita saksikan bagaimana kemampuan teknologi memanipulasi realitas kehidupan. Sebagai contoh kecanggihan teknologi menyuguhkan reklame media elektronik yang mampu dengan cepat "membius" para pelanggan. Reklame media elektronik inilah salah satu faktor dominan yang merubah karakter dan kultur masyarakat Indonesia dari pekerja keras menjadi lebih konsumtif. Kultur inilah yang menjadi teman akrab dari materialisme. Pada dimensi yang lain kemajuan teknologi juga telah membawa spesialisasi dan deferensiasi dalam kehidupan. Manusia menjadi menonjol karena keahlian dan spesialisasnya. Hal ini sangat kuat karena pengaruh pandangan monodisiplin yang kalau dibedah menjadi bagian-bagian akan melahirkan spesialisasi. Kalau perkembangan ini tidak dikontrol tentu akan melahirkan karakter kehidupan manusia yang cenderung terpecah atau terbagi-bagi, tidak utuh lagi (I Gde Widja, 1991: 3). Akibatnya akan melahirkan manusia-manusia yang individualis, merenggangkan tali silaturahmi antarsesama (bisa dirasakan dalam kehidupan sekarang). Bahkan lebih jauh akan melahirkan manusia yang egois. Kalau ini berkepanjangan tentu tidak akan mampu melahirkan kekuatan insan pembangunan keindonesiaan yang kokoh. Bahkan sebaliknya dapat melahirkan berbagai konflik sosial-politik yang semakin meningkat, intoleransi terus menggejala, penyimpangan sosial kian meningkat baik dalam jenis dan bentuknya, krisis identitas, dan lain-lain.

Di samping itu perkembagan teknologi yang tidak terkontrol juga berdampak pada dekadensi moral dan anarkhisme. Naroka, pornogfafi dan pornoaksi, serta tidak kekerasan dalam berbagi bentuk. Tidak hanya itu dengan teknologi ini juga bisa mendorong orang berlaku tidak jujur yang dapat mendorong bertindak korup. Budaya asing juga semakin digandrungi oleh sebagian masyarakat kita, sehingga menunjukkan tanda-tanda lunturnya jati diri keindonesiaan. Begitu juga dengan AFTA tahun 2015 bagaimana sumber daya insani kita mampu survive. Nampaknya pelaksanaan pendidikan nasional kita belum mampu membendung pengaruh negatif dari teknologi. Bahkan dengan pengaruh teknologi pendidikan juga cenderung pragmatis dan inteletualistik. Akibatnya aspek kepribadian dan karakter manusia kurang mendapat perhatian. Lahirnya pendidikan karakter di Indonesia menunjukkan bahwa pelaksanaan pendidikan selama ini gagal menciptakan kepribadian bangsa yang luhur. Dari uraian tersebut menunjukkan bahwa masalah-masalah sosial kebangsaan di Indonesia masih begitu kompleks.

\section{Ide Pemikiran Integratif /Bagaimana Pe- ran IPS ?}

Mampukan pembelajaran IPS memberikan kontribusi untuk ikut mengatasi berbagai masalah sosial yang ada di Indonesia? Kalau kita melakukan komparasi dengan negaranegara lain akan mendapatkan pengalaman bagaimana pelajaran IPS di negara-negara lain juga dapat memberikan kontribusi dalam memecahkan masalah kehidupan sosial di negaranya. Sebagai contoh dapat dilihat di Inggris. Pertama kali IPS yang dikenal dengan social studies ini diperkenalkan di kota Rugby, Inggris sekitar tahun 1827. Oleh Thomas Arnold social studies ini kemudian dimasukkan dalam kurikulum sekolah yang dipimpinnya. Social studies ini dimaksudkan sebagai pelajaran untuk memperbaiki kehidupan remaja dan masyarakat yang sedang kacau seperti tindak diskriminasi, dekadensi moral, anarkhisme dan kekerasan dari si kaya kepada si papa dan miskin. Kehidupan ini terjadi setelah sekitar setengah abad terjadinya revolusi industri Di benak Thomas Arnold social studies merupakan salah satu instrumen penting untuk mengatasi kebobrokan kehidupan masyarakat di Inggris. Dengan social studies ini Thomas Arnold ingin melakukan rehumanisasi anak-anak yang fisik dan jiwanya masih lentur. Secara bertahap eksperimen Thomas Arnold ini membuahkan hasil. (Esterlita Pratiwi, 2011). Dimulai dari perbaikan perilaku para peserta didik dengan lingkungannya kemudian ditiru oleh sekolah-sekolah dan guru-guru yang lain. Terjadi proses normalisasi kehidupan bermasyarakat di Inggris.

Kemudian di Amerika Serikat muncul 
permasalahan kehidupan bermasyarakat dan berbangsa setelah terjadi Perang Saudara (1861-1865) (lih. NCSS.1994). Masyarakat menjadi trauma dan bersifat pasif, tidak partisipatif. Kondisi ini sangat tidak menguntungkan bagi negara yang sangat menghiduphidupkan demokrasi. Kondisi multi ras juga menjadi permasalahan penting dalam rangka memajukan Amerika yang satu. Para ahli berpikir bagaimana menciptakan kehidupan yang lebih harmoni di Amerika Serikat. Dirintislah oleh sekolah-sekolah di negara bagian Wisconsin yang membelajarkan social studies sejak tahun 1892 (Pargito,2010). Nilainilai seperti toleransi, transparansi, tanggung jawab, kebersamaan untuk menciptakan satu Amerika merupakan nilai-nilai diperjuangkan untuk ditanamkan kepada peserta didik. Pada tahun 1916 Panitia Nasional Pendidikan Menengah menyetujui untuk memasukkan social studies ke dalam kurikulum sekolah. Secara umum Amerika Serikat berhasil mengembangkan pembelajaran social studies di sekolah. Hal ini semakin mantap setelah terbentuknya National Council for The Social Studies (NCSS). NCSS kemudian merumuskan konsep social studies sebagaimana dirintis Edgar Bruce Wesley dengan cara melakukan seleksi, penyederhanaan, adaptasi, yang kemudian merumuskan serta memadukan aspek-aspek dari cabang-cabang ilmu-ilmu sosial dan humaniora. Pada akhir tahun 1960 secara eksplisit sudah ada pemisahan dalam konteks kajian akademik antara substansi kajian social sciences dengan social studies. Social studies semakin memantapkan diri dengan ciri terpadu dan interdisipliner. Selama kurun waktu 1937-1970-an pembelajaran social studies dinilai berhasil membantu memecahkan berbagai problem sosio kebangsaan di Amerika Serikat.

Berdasarkan pengalaman dua negara maju itu, Indonesia juga merencanakan perlunya mata pelajaran social studies di Indonesia. Para ahli pendidikan di Indonesia memandang keberhasilan pembelajaran social studies di Amerika dan Inggris itu, menunjukkan bahwa mata pelajaran social studies merupakan instrumen penting dalam mengatasi permasalahan sosial di suatu negara. Ren- cana perlunya mata pelajaran social studies di Indonesia didorong oleh kondisi sosial kebangsaan terutama setelah peristiwa G. 30.S/ PKI. Trauma karena kekerasan dan hilangnya trust antarsesama komponen bangsa, harus segera diatasi. Persatuan dan kebersamaan harus dikembangkan di tengah-tengah dilarangnya ideologi komunis di Indonesia. Toleransi harus dibangun di tengah-tengah keberagaman ideologi, budaya dan agama. Dengan realitas itu Indonesia ingin mengembangkan pembelajaran social studies di sekolah. Tahun 1972/1973, social studies yang diberi nama Ilmu Pengetahuan Sosial (IPS) menjadi salah satu mata pelajaran pada Kurikulum Proyek Perintis Sekolah Pembangunan (PPSP). Kemudian sejak tahun 1975 secara resmi mata pelajaran IPS menjadi salah satu mata pelajaran di sekolah.

IPS dapat dikatakan sebagai studi mengenai interrelasi ilmu-ilmu sosial dan humaniora dalam menelaah gejala dan masalah sosial yang terpadu di masyarakat (Nursid Sumaatmadja, 1980). Bahan kajiannya menyangkut peristiwa, seperangkat fakta, konsep dan generalisasi yang berkait dengan isu-isu aktual dan masalah-masalah sosial. Sementara itu, National Council for Social Studies (NCSS) menegaskan bahwa, "Social studies are the integrated study of the social sciences and humanities to promote civic competence. Within the school program, social studies provides coordinated, systematic study drawing upon such disciplines as anthropology, archaeology, economics, geography, history, law, philosophy, political science, psychology, religion, and sociology, as well as appropriate content from the humanities, mathematics, and the natural sciences " (1994). Terkait dengan pengertian ini, M. Numan Somantri (2001) menegaskan bahwa program pendidikan IPS merupakan perpaduan cabang-cabang Ilmu-ilmu sosial dan humaniora termasuk di dalamnya agama, filsafat, dan pendidikan. Bahkan IPS juga dapat mengambil aspek-aspek tertentu dan Ilmu-ilmu kealaman dan teknologi. Dengan pengertian itu berarti IPS merupakan pelajaran yang cukup komprehensif untuk menyikapi dan memecahkan masalah-masalah sosio-kebangsaan di Indonesia. Oleh karena itu 
S. Hamid Hasan (2010) menegaskan bahwa IPS adalah studi integratif tentang kehidupan manusia dalam berbagai dimensi ruang dan waktu dengan segala aktivitasnya. Konsep seperti ini terutama untuk pengembangan materi (isi) IPS di tingkat pendidikan dasar (SD dan SMP dan sederajat).

Bagaimana arah dan tujuan pendidikan IPS? Melalui pendidikan dan pembelajaran IPS peserta didik diarahkan, dibimbing dan dibelajarkan agar menjadi warga negara yang memiliki kepekaan, dan kemampuan memahami, menelaah dan ikut memecahkan masalah-masalah sosial kemasyarakatan dan kebangsaan, serta mewarisi dan mengembangkan nilai-nilai luhur budaya bangsa. Terkait dengan ini, maka tujuan pendidikan dan pembelajaran IPS adalah agar peserta didik : (1) mengembangkan kemampuan berpikir untuk dapat memahami, menyikapi, beradaptasi dan memecahkan masalah sosial; (2) serta memahami, memorial dan melanjutkan kebudayaan bangsa. Dengan arah dan tujuan ini diharapkan tercipta warga negara yang baik dan bijaksana, kritis dan kreatif, demokratis dan tanggung jawab, menumbuhkan semangat kebangsaan dan memperkokoh jati diri bangsa, serta membangun kesadaran dan menumbuhkan kepedulian terhadap lingkungan. Oleh karena itu melalui pembelajaran IPS, peserta didik diharapkan memiliki beberapa kompetensi antara lain:

1. Memahamikehidupan masyarakat dalam berbagai aspek dan lingkungannya

2. Memiliki kemampuan dasar untuk berpikir logis dan kritis, rasa ingin tahu, inkuiri (learning skills), memecahkan masalah, memiliki kesadaran dan keterampilan sosial (social skills) dalam kehidupan bermasyarakat

3. Memiliki kesadaran terhadap nilai-nilai sosial-budaya, kebangsaan, dan kemanusiaan serta kepribadian yang didasarkan pada nilai-nilai tersebut

4. Memiliki kemampuan berkomunikasi, bekerjasama dan berkompetisi dalam masyarakat yang majemuk, di tingkat lokal, nasional, dan global.
Makna dan tujuan pendidikan IPS yang demikian itu kalau dlaksanakan secara sungguh-sunguh tentu akan memberi andil dan survive dalan menghadapi masa depan.

\section{Problem yang Dihadapi}

Secara konseptual, arah dan tujuan IPS itu sudah sangat jelas. Namun dalam praktik pebelajaran di lapangan sejak secara resmi tahun 1975 dikembangkan, dengan berbagai perubahan kurikulum sampai KTSP dan Kurikulum 2013, masih menghadapi problem klasik yang belum pernah terselesaikan.. Pertama, soal substansi isi dan kedua, pelaksanaan pembelajaran di sekolah. Sesuai dengan pengertian IPS di atas ciri utamanya adalah terpadu. Tetapi dalam kenyataannya memang belum ada substansi isi mata pelajaran IPS yang dikatakan terpadu. Semua ahli dan pemangku kepentingan yang terkait dengan IPS. Desain isi/materi IPS masih berangkat dari empat bidang keilmuan: geografi, sejarah, ekonomi dan sosiologi. Belum ada pemikiran yang mendasar (bahkan mungkin radikal) untuk keluar dari keempat bidang keilmuan dan menyusun substansi yang baru sesuai dengan perkembangan dan kebutuhan masyarakat. Di atas sudah dipaparkan berbagai masalah sosial kebangsaan dengan segala latar belakang mengapa timbul masalah itu. Dalam konteks ini artinya masyarakat memerlukan agar masalahan sosial kebangsaan itu dapat diatasi. Untuk dapat mengatasi masalah sosial materi atau substansi kajian apa yang harus dibelajarkan kepada peserta didik. Jawaban ini yang jarang muncul dalam desain kurikulum di Indonesia. Senyampang dengan pemecahan masalah tersebut peserta didik diharapkan juga menjadi sadar IPTEKS, kreatif dan beretika.

Sementara dalam pelaksanaan pembelajaran di sekolah umumnya sangat sulit terjadi perubahan kearah pembelajaran yang yang mengarah kepada pembelajaran yang kontekstual, kreatif dan mampu memecahkan masalah. Berbagai bentuk pelatihan tingkat nasional sudah dilakukan. Misalnya ada P3G, pelatihan terintegrasi, pelatihan pembelajaran terpadu. Kendala yang muncul adalah sulitnya bagi para guru dalam merubah mind- 
set. Berikutnya guru-guru menjadi trauma karena mengajar IPS itu beban materinya sangat berat/banyak, terutama periode KTSP. Karena IPS diterjemahkan kumpulan dari materi geografi, ditambah sejarah, ditambah sosiologi dan juga ekonomi. Pada Kurikulum 2013 berusaha kesan gabungan materi IPS yang merupakan akumulasi materi geografi, sejarah, sosiologi dan ekonomi sudah di deasin agak mencair agar terasa terpadu, tetapi nuansa gabungan keempat bidang keilmuan itu masih kental (belum berani keluar dari jeratan empat bidang itu).

\section{Sebuah Alternatif}

Berangkat dari uraian di atas nampaknya perlu langkah baru sebagai aternatif dengan mengembangkan standar isi untuk pembelajaran IPS di Indonesia, terutama untuk jenjang SMP dan yang sederajat. Pada Kurikulum 2013 sudah dicoba dikembangkan, namun nuansa materi masih terasa berlapis dari empat bidang ilmu (geografi, sejarag, sosiologi, dan ekonomi). Kalau dikaitkan dengan kajian konseptual dan tujuan pembelajaran IPS, masih perlu dikembakan atau dimodifikasi yang lebih komprehensif, terpadu.dan kotekstual tetapi juga lebih efisien.

Pada tahun 2010 Prof S. Hamid Hassan, pernah menjelaskan bahwa untuk merumuskan Standar Kompetensi Lulusan untuk IPS perlu memperhatikan dua hal, yakni performance standards dan content standards (S. Hamid Hassan, 2010). Performance standards IPS merupakan nilai dan kemampuan unjuk kerja/perilaku yang harus dikuasai atau dimiliki oleh peserta didik setelah melakukan proses pembelajaran IPS. Perpaduan interaksional antara Content standards merupakan materi kajian yang mengandung berbagai pesan yang diperlukan untuk mencapai kompetensi. Dengan demikian dalam SKL, antara standar unjuk kerja dengan standar materi tidak dapat dipisah-pisahkan.

Sesuai dengan konsep dan tujuan pembelajaran IPS, maka dapat dirumuskan nilai dan kemampuan unjuk kerja (performance standards) pada mata pelajaran IPS, misalnya:

1. kemampuan berpikir logis, kritis, rasa ingin thu, kreatif dan inovatif.

2. kemampuan inkuiri dan pemecahan masalah sosial

3. kemampuan berkomunikasi dan membangun jejaring

4. keterampilan mengambil keputusan dengan tepat dan bijak.

5. kepedulian terhadap lingkungan.

6. menghargai dan menyayangi antar sesama

7. cinta bangsa dan tanah air

8. meneladani para tokoh dan pahlawan

9. menghargai, mencintai budaya dan produk bangsa sendiri

10. jujur dan cinta kebenaran,

11. disiplin dan kerja keras,

12. toleransi dan menghargai keberagaman

13. kemampuan berorganisasi, kerja sama, dan cinta damai

14. melaksanakan kewajiban dan menggunakan hak secara proporsional

15. demokratis, adil dan tanggung jawab

16. bertindak efektif dan efisien

17. mandiri dan berani mengambil resiko

Pencapaian kemapuan atau untuk mewujudkan performance standards, diperlukan standar isi/materi. Ruang lingkup standar isi/materi IPS, tentu terkait erat dengan bidang kajian yang termasuk dalam unsurunsur IPS. Di dalam UU no. 20 th. 2003 tentang Sisdiknas pasal 37 dijelaskan bahwa ilmu pengetahuan sosial merupakan bahan kajian yang wajib dimuat dalam kurikulum pendidikan dasar dan menengah yang antara lain mencakup ilmu bumi, sejarah, ekonomi, kesehatan , (sosiologi) dan lain sebagainya. Terkait dengan kata-kata dan lain sebagainya, sebenarnya materi kajian IPS tidak terbatas pada geografi, sejarah, sosiologi, dan kesehatan, tetapi juga bisa disipilin dan kajian yang lain seperti ilmu-ilmu dalam rumpun humaniora, teknologi, bahkan ilmu-ilmu kealaman dan agama yang memang terkait dengan kehidupan sosial kemasyarakatan (lih. M. Numan Soemantri, 2001). Terkait dengan itu berikut disajikan bebera contoh tema-tema utama yang relevan dengan IPS di Indonesia.

1. Manusia, individu, dan Tuhan 
2. Tempat, ruang, lingkungan, dan kebencanaan

3. Waktu, keberlanjutan, perkembangan dan perubahan

4. Sistem sosial dan budaya, struktur sosial, interaksi sosial

5. Kekuasaan, kewenangan, dan pemerintahan.

6. Pemenuhan kebutuhan, kesejahteraan, kelangkaan, ketergantungan.

7. Masyarakat, ilmu pengetahuan dan teknologi.

8. Globalisasi, dan kerjasama internasional.

Setelah mengetahui nilai dan kemampuan unjuk kerja (performance standards) dan tema-tema utama (content standards), kemudian dapat dirumuskan SKL.dapat juga dengan meminjam format Kurikulum 2013 untuk dirumuskan Kompetensi Inti (KI) dan Kompetensi Dasar (KD)-nya. Sebagai bahan referensi untuk membuat urutan dapat diperhatikan apa yang pernah dilakukan Savage dan Amstrong dalam menyusun tematema umum pelajaran social stuidies dengan tiga sasaran pembelajaran: pengetahuan, keterampilan dan nilai yang disesuaikan dengan tingkat perkembangan peserta didik.

1. Pra sekolah : Kesadaran diri di tengah masyarakat

2. Kelas satu: Lingkungan keluarga dan sekolah

3. Kelas dua: Kehidupan bertetangga

4. Kelas tiga: Berbagi kehidupan dalam masyarakat

5. Kelas empat: Keragaman kehidupan dalam masyarakat dalam suatu wilayah

6. Kelas lima: Penduduk Amerika dan negara sekitar

7. Kelas enam: Manusia dan kebudayaan di suatu wilayah

8. Kelas tujuh: Perubahan kehidupan berbangsa

9. Kelas delapan: Membangun bangsa yang kuat dan merdeka.

Dengan referensi tersebut dapat dirumuskan tema-tema umum mata pelajaran IPS dari kelas I sampai dengan IX (disesuai- kan dg. Kondisi Indonesia), sebagai berikut.

1. Kelas satu : Pengenalan Tuhan Yang Maha Pencipta, Individu, keluarga dan lingkungannya.

2. Kelas dua: Pengenalan Keluarga, tetangga, dan sekolah

3. Kelas tiga : Kehidupan masyarakat di wilayahnya

4. Kelas empat : Keragaman keadaan alam dan kehidupanmasyarakat di berbagai wilayah

5. Kelas lima: Penyatuan wilayah dan ide wilayah KesatuanIndonesia

6. Kelas enam: Perkembangan Wilayah, eksistensi bangsa Indonesia

7. Kelas tujuh: Perubahan Kehidupan Berbangsa Indonesia

8. Kelas delapan: Dinamika Kehidupan Berbangsa dan Bernegaradi Indonesia.

9. Kelas sembilan: Memperkuat jati diri bangsa di Tengah Dunia Global.

Dari nilai-nilai dan kemapuan unjuk kerja kemudian dipadukan dengan tema-tema utama dapat dirumuskan SKL dari kelas I sampai dengan IX. Berikut diberi contoh untuk kelas VII, VIII dan IX.

1. Kelas tujuh: Memahami perkembangan kehidupan penduduk/bangsa Indonesia, untuk menambah pengetahuannya mengenai latar belakang kondisi alam dan kehidupan masyarakat sampai terjadinya perubahan kehidupan berbangsa dan terwujudnya NKRI, kemudian dapat mengatualisasikan dan mengkomunikasikan lewat berbagai media, dalam rangka meningkatkan keimanan dan rasa syukur atas anugerah Tuhan YME, mengembangkan berpikir kritis, faktual, menghargai dan mencintai kekayaan alam dan budaya Indonesia, menghargai kemajemukan dan toleransi, menumbuhkembangkan semangat kebangsaan dan cinta tanah air, menghargai kemerdekaan secara bertanggung jawab, demokratis, menyadari dan mengambil pelajaran dari berbagai perubahan yang terjadi, disiplin, tertib, mandiri, rela berkorban, kerja keras, membangun kebersamaan 
untuk memperkokoh NKRI atas dasar nilai-nilai Pancasila.

2. Kelas delapan: Menganlisis dinamika kehidupan berbangsa dan bernegara dengan menganalisis sistem dan kebijakan pembangunan di bidang politik dan ekonomi serta masalah-masalah sosiokebangsaan (masalah-masalah sosial, ekonomi, politik dan budaya bangsa Indonesia), kemudian dapat mengaktualisasikan dan mengkomunikasikan lewat berbagai media, dalam rangka meningkatkan keimanan dan rasa syukur kepada Tuhan YME atas karunia-Nya, untuk melatih berpikir kritis, inovatif, mengambil pelajaran dari berbagai masalah sosial dan kemudian ikut berpartipasi dalam pemecacahan maasalah-masalah itu, sehingga menghindari berbagai bentuk pelanggaran, melaksanakan hidup tertib, disiplin sesuai dengan aturan, dan norma yang berlaku, kepedulian terhadap lingkungan dan kebencanaan, kedewasaan berpolitik dan saling menghormati termasuk menghargai simbol dan lambanglambang Negara.

3. Kelas Sembilan: Menganalisis dan ikut berpartisipasi dalam membangun jati diri bangsa di tengah-tengah dunia global, ke- mudian dapat mengatualisasikan dan mengkomunikasikan lewat berbagai media, dalam rangkan meningkatkan keimanan dan rasa syukur kepada Tuhan YME atas karunia-Nya, untuk mengembangkan berpikir kritis, kreatif, inovatif, menelaah secara kritis berbagai bentuk dan usaha pembangunan serta praktek kehidupan demokrasi, memperkokoh ideologi Negara termasuk menghargai dan menghormati lambang atau simbol-simbol negara, meneladani perjuangan para tokoh pemimpin bangsa, membangun kemandirian, mencintai dan ikut menjaga/melestarikan budaya serta produk bangsa sendiri, memhamai globalisasi, mencintai perdamaian, menghargai dan menelaah berbagai karya dan pengaruh budaya manca secara kritis dan selektif untuk memperkokoh eksistensi dan jati diri bangsa.

Dengan perpaduan interaksional antara performance standards dan content standard, maka dari SKL (dengan meminjam format Kurikulum 2013) akan diturunkan menjadi Kompetensi Inti (KI) tetapi subtansi isi berbeda, dari KI dapat dijabarkan menjadi kompetensi dasar.

\begin{tabular}{|c|c|c|}
\hline Kelas & Kompetensi Inti & Kompetensi Dasar \\
\hline \multirow[t]{3}{*}{ VII } & $\begin{array}{l}\text { Memahami Latar Belakang } \\
\text { Kehidupan Bangsa } \\
\text { Indonesia dan implikasinya } \\
\text { bagi kehidupan } \\
\text { bermasyarakat, berbangsa }\end{array}$ & $\begin{array}{l}\text { 1. Menganalisis keberagaman kondisi alam dan batas-batas Wilayah } \\
\text { Kepulauan Indonesia untuk berlatih berpikir kritis, menumbuhkan } \\
\text { rasa syukur dan meningkatkan keimanan, rasa bangga terhadap } \\
\text { kekayaan dan keindahan alam Indonesia, sehingga menumbuhkan } \\
\text { rasa percaya diri dan terdorong untuk melestarikan. }\end{array}$ \\
\hline & & $\begin{array}{l}\text { 2. Mendeskripsikan keragaman penduduk dan mata pecahariannya., } \\
\text { untuk berlatih berpikir logis, arif. menumbuhkan rasa syukur ke- } \\
\text { pada Tuhan, saling menghargai, kerja sama, toleransi, percaya diri } \\
\text { dan saling berbagi. }\end{array}$ \\
\hline & & $\begin{array}{l}\text { 3. Mendeskripsikan latar belakang kehidupan sosial politik, } \\
\text { pemerintahan; dan keragaman sosial budaya, untuk berlatih } \\
\text { berpikir kritis, faktual; sikap patriotik mengembangkan toleransi } \\
\text { dan saling menghargai, menumbuhkan kecerdasan emosional } \\
\text { melalui kearifan lokal, dan bangga terhadap karya budaya bangsa. }\end{array}$ \\
\hline
\end{tabular}


Memahami terwujudnya Integrasi Nasional untuk mengembangkan rasa persatuan dan memperkokoh identitas nasional

1. Menganalis kemajemukan dalam kehidupan masyarakat (suku, golongan, organisasi), dalam rangka menumbuhkan rasa syukur, melatih berpikir logis, kritis, kemampuan memecahkan masalah, menumbuhkan rasa saling menghargai, toleransi, berbagi/memberi, dan menyadari pentingnya kemajemukan sebagai kekuatan bangsa.

2. Menganalisis terwujudnya Integrasi Nasional, lahirnya bangsa Indonesia dan Perubahan Kehidupan Berbangsa, untuk meningkatkan rasa syukur dan keimanan, berlatih berpikir kritis, menumbuhkan rasa syukur, semangat kebangsaan dan rasa persatuan, menyadari pentingnya kemerdekaan dan perubahan untuk kemajuan, disiplin, kerja keras, menumbuhkan semangat untuk mempertahankan NKRI

3. Mengembangkan kehidupan yang demokratis dan bertanggung jawab, untuk melatih berpikir kritis, kemampuan memecahkan masalah, kerjasama dan senang bermusyawarah. saling menghormati, menghargai perbedaan, mengembangkan kemampuan berkomunikasi dan menyampaikan pendapat.

4. Mendeskripsikan kepemimpinan lokal dan nasional, untuk melatih berpikir kritis, kreatif-inovatif, menumbuhkan jiwa kepemimpinan dan tanggung jawab, membangun kecerdasan emosional dan spiritual dengan meningkatkan rasa syukur melalui kearifan lokal

VIII Menganalisis sistem dan kebijakan pembangunan di bidang politik, ekonomi dan sosial budaya untuk menumbuhkan rasa syukur, dan semangat juang untuk mencapai kesejahteraan

1. Menganalisis sistem dan kegiatan pembangunan di bidang politik dan pemerintahan, untuk berlatih berpikir kritis, kreatif, membangun kesadaran berpolitik dan berorganisasi, secara bertanggung jawab, dan sikap yang demokratis, mengembangkan etos kerja keras.

2. Menganalisis sistem dan kegiatan pembangunan di bidang ekonomi dalam rangka mengembangkan kegiatan ekonomi yang bermoral dan bertanggung jawab, untuk berlatih berpikir kritis, analistis, kerjasama, kemauan untuk berbagi, membangun kejujuran, keikhlasan dan kesyukuran

3. Mendeskripsikan kegiatan pembangunan di bidang transportasi, komunikasi dan informasi dalam rangka berlatih berpikir kritis dan inovatif, mengembangkan etika dan kesiplinan dalam berlalu lintas, penggunaan alat komunikasi dan pemanfaatan informasi secara bertanggung jawab.

4. Menganalisis arti pentingnya keamanan dan ketertiban masyarakat dalam kegiatan pembangunan, untuk berlatih berpikir kritis, membangun kesadaran sosial untuk selalu bergotong royong, saling membantu, hidup tertib sesuai dengan ketentuan yang ada, tanggung jawab

Memahami dan menumbuhkebangkan kepedulian terhadap masalah-masalah sosiokebangsaan
1. Menganalisis masalah kependudukan untuk berlatih berpikir kritis faktual, keterampilan memecahkan masalah yang terkait dengan penyebaran penduduk, ketenagakerjaan, dan kesehatan masyarakat 
2. Memiliki kesadaran dan kepedulian terhadap Masalah Lingkungan untuk menyelamatkan lingkungan demi keselamatan makhluk ciptaan Tuhan

3. Menganalisis Masalah Penyimpangan sosial untuk mengambil pelajaran agar bersikap dan berperilaku sesuai dengan ketentuan dan norma yang ada, meingkatkan keimanan.

4. Mendeskripsikan masalah yang terkait dengan berbagai penyakit sosial, agar dapat mengambil pelajaran untuk kemudian hidup tertib, tidak menyimpang dan tidak melakukan hal-hal yang membahayakan bagi dirinya dan masyarakat

5. Menganalisis berbagai masalah sosio-kebangsaan untuk menjadi pelajaran, sehingga menjadi warga negara yang baik, warga negara yang tidak merugikan negara dan masyarakat, tidak mengancam keutuhan bangsa, dan berbuat disiplin, lurus untuk meneguhkan citra Indonesia sebagai negara hukum

IX Memahami usaha Penguatan jati diri bangsa dalam rangka membangun kemandirian dan kejayaan negara di tengah dunia global
Memahami perspektif Global dalam meneguhkan identitas nasional dan kehidupan berbangsa bernegara
1. Menganalisis Penguatan kehidupan demokrasi untuk berlatih berpikir kritis-analitis, bersikap jujur dan saling menghormati, berusaha menjunjung tinggi harkat dan martabat bangsa melalui kehidupan demokrasi yang bertanggung jawab.

2. Mendeskripsikan pembangunan bidang IPTEK dan sosial budaya untukmeningkatkan rasa syukur, berlatih berpikir kritis, kreatif dan inovatif, membangun kearifan dan toleransi, kemampuan memberikan penilaian dan memecahkan masalah untuk kemaslahatan orang banyak, membangun kemandirian dan menghargai karya bangsa sendiri

3. Menganalisis pembangunan di bidang SDM untuk berlatih berpikir kritis, kreatif, menyadari pentingnya peran pendidikan dalam menciptakan SDM yang berkualitas, menyadari bahwa SDM yang berkualitas menjadi modal dasar untuk mencapai kemandirian dan keunggulan bangsa

4. Menganalisis Peran Pancasila dan simbol-simbol negara dalam pengembangan karakter bangsa.

1. Mengenali perkemabangan negara-negara lain dan pengaruhnya bagi kehidupan bangsa Indonesia untuk berlatih berpikir kritis, bersikap arif dan saling menghargai, belajar cerdas dari bangsa lain untuk meneguhkan kemandirian bangsa

2. Mendiskripsikan kerja sama internasional, untuk berlatih berpikir kritis, kreatif, menyadari pentingnya kerja sama dan saling menghormati, saling ketergantungan dan kemauan untuk mengambil pelajaran demi kemajuan dirinya dan masyarakat secara nasional.

3. Menganalisis isu-isuGlobal, untuk melatih berpikir kritis, bersikap arif, dan mengambil pelajaran untuk kepentingan bangsa

4. Memahami perspektif Global dalam meneguhkan identitas nasional dan kehidupan berbangsa bernegara Memahami perspektif Global dalam meneguhkan identitas nasional dan kehidupan berbangsa bernegara Mendeskripsikan tentang perdamaian dunia, untuk berlatih berpikir kritis, kreatif, menyadari pentingnya perdamaian, , bangga terhadap bangsa dan negara Indonesia yang telah ikut berperan dalam mewujudkan perdamaian dunia 


\section{SIMPULAN}

Masalah-masalah sosial kebangsaan yang begitu kompleks di Indonesia sudah semestinya menjadi fokus perhatian bagi pendidikan dan pembelajaran IPS, mengingat IPS memiliki materi kajian yang luas dan terpadu. Harus diakui bahwa pendidikan IPS selama ini belum mampu memberikan kontribusi yang signifikan dalam ikut memecahkan masalah kehidupan bermasyarakat dan berbangsa. Pasalnya, secara interen dalam pendidikan IPS masih menghadapi persoalan antara lain dari segi konsep isi dan pelaksanaan pembelajaran. Dari segi isi sesuai dengan konsep IPS jelas memiliki unsur-unsur yang lebih komprehensif, tidak cuku hanya aspek-aspek geografi, sejarah, sosiologi dan ekonomi tetapi lebih luas dari itu dan ini sesuai dengan masalah-masalah yang dihadapi di Indonesia. Oleh karena itu, pada tingkat jenjang pendidikan dasar, terutama di SMP dikembangkan pendidikan IPS yang integrated baik disain substansi kajian maupun model pembelajarannya (Fogarty, 1991)

\section{DAFTAR PUSTAKA}

Esterlita Pratiwi. 2012. Dalam http://esterlitapratiwi, blogspot.com/2011, diunduh 9 September 2012.

Fogarty, Robin. 1991. The Mindful School: How to Integrated the Curricula, Palatine, Illinois: Skylight Publishing, Inc.

Hassan, S. Hamid. 2010. "Pendidikan IPS (Definisi,Tujuan, SKL, Konten, Proses dan Asesmen)" Panduan. Yogyakarta: HISPISI. NCSS. 1994. Curriculum Standars for the Social Studies. Washington D.C.: National Council for the Social Studies.

Pargito. 2010. Dalam http://haslindafadilah.blogspot.com/2010, diunduh pada 10 September 2012 .

Sardiman AM. 2011. "Gagasan Standar Isi IPS" Bahan Rapat, Yogyakarta. 2012. "IPS dan Tantangan Masa Depan". Makalah Orasi Ilmiah, Dies Natalis FIS UNY, 15 September, 2012.

Somantri, M. Numan. 2001. Menggagas Pembaharuan Pendidikan IPS. Bandung:Rosda Karya.

Widja, I Gde. 1991. " Pendidikan Sejarah dan Tantangan Masa Depan,” Makalah Orasi Ilmiah, Disampaikan pada pengukuhan Guru Besar Tetap pada Ilmu Pendidikan Sejarah FKIP Universitas Udayana. 19 Januari 1991.

Zamroni. 2011."Transformasi Pembelajaran IPS Guna Memantapkan Peran Nilai-nilainya Dalam Pembangunan Karakter Bangsa", Makalah, disampaikan di UHAMKA pada Kongres HISPISI XIII, 7-9 Oktober. 